\title{
The Effects of Nitrogen and Phosphorus Fertilizer Rates on Yield and Quality of Tomato (Solanum lycopersicum L.) in Hawzen, Ethiopia
}

Hilay Gebremedhin ( $\nabla$ gnhailush2@gmail.com )

Adigrat University College of Agriculture https://orcid.org/0000-0001-6883-0666

Mehari Gebremicheal

Adigrat University College of Agriculture

Gebregwergis Fitsum

Adigrat University College of Agriculture

\section{Research}

Keywords: fertilizer, fruit yield, mineral composition, quality, tomato

Posted Date: September 30th, 2020

DOI: https://doi.org/10.21203/rs.3.rs-80064/v1

License: (c) (1) This work is licensed under a Creative Commons Attribution 4.0 International License.

Read Full License 


\section{Abstract \\ Background}

More than $50 \%$ of the soil in Tigray is deficient in macro essential nutrients. Hence, poor soil chemical fertility is a major challenges for low production of crops like tomato in Hawzen. The aim of this work was to study the effects of $N$ and $P$ rates on the yield and quality of tomato (Solanum lycopersicum L.) in Hawzen, Tigray, Ethiopia.

\section{Methods}

Four different rates of $\mathrm{N}\left(0,69,138\right.$ and $\left.207 \mathrm{~kg} \mathrm{Nha}^{-1}\right)$ and $\mathrm{P}\left(0,46,69 \& 92 \mathrm{~kg} \mathrm{Pha}^{-1}\right)$ were laid out in a randomized complete block design with three replications. Soil analysis were done before executing of the experiment. Data were collected on yield, and fruit quality of tomato.

\section{Results}

The results revealed that plant height, leaf area index, number of primary branches per plant, number of clusters per plant, number of flower clusters, number of fruit per clusters and fruit set were significantly influenced by the main effects of $\mathrm{N}$ and $\mathrm{P}$ rates. The interaction of $\mathrm{N}$ and $\mathrm{P}$ rates only had significant effects on marketable, total fruit yield, mean fruit weight, and fruit length. Compared to control, application of $138 \mathrm{~kg} \mathrm{Nha}^{-1}$ and $69 \mathrm{~kg} \mathrm{Pha}^{-1}$ increased mean fruit weight, marketable fruit weight and total fruit yield by $35.9 \%, 70.5 \%$ and $68.4 \%$, respectively. Likewise, the main effects of $\mathrm{N}$ and $\mathrm{P}$ rates were remarkable on total soluble solids, total sugar, titratable acidity, ascorbic acid, lycopene content, and protein. A significant influence on the $\mathrm{P}$ content of tomato was detected due to varied rates of $\mathrm{P}$. fruit $\mathrm{N}$ concentration was significantly influenced by rates of $\mathrm{N}$ only.

\section{Conclusion}

Application of $\mathrm{N}$ and $\mathrm{P}$ at rates of 138 and $69 \mathrm{kgha}^{-1}$, respectively, showed the highest values in most yield and quality measurements and particularly increased yield by $70.5 \%$ as compared to the nil fertilizer application. Therefore, $138 \mathrm{~kg} \mathrm{Nha}^{-1}$ and $69 \mathrm{~kg} \mathrm{Pha}^{-1}$ can be used by producers for better yield and quality of tomato in the area.

\section{Background}

Tomato (Lycopersicon esculentum Mill) is important in the daily diet and economy of Ethiopian people. It is an important source of income for small-scale farmers and sources of employment for many people and regional export crops (Wiersinga and de Jager, 2009). According to Gemechis et al. (2012), it is 
consumed in every household in different modes, but in certain areas, it is also an important co-staple food and source of vitamins and minerals. One medium ripe tomato fruit can provide up to $40 \%$ of the recommended daily allowance of vitamin C and $20 \%$ of vitamin A (Kelly and Boyhan, 2010). It also has beta-carotene, which is an antioxidant and promotes good health (Willcox et al., 2003). Tomatoes also contain lycopene, a red pigment serving as a natural antioxidant (Shi and Manguer, 2000), calcium, water, and niacin, which are essential for metabolism (Olaniyi et al., 2010).

In Ethiopia, vegetables cover approximately $1.67 \%$ of the area under all crops and contribute $2.23 \%$ of the production of the total crop at a national level (CSA, 2019). Tomato production in Tigray is approximately $26.5 \%$ of the vegetable production area (CSA, 2017). However, the productivity is very low, approximately 5.7 ton ha- ${ }^{-1}$ (CSA, 2017), compared to Egypt (18.6 ton ha ${ }^{-1}$ ), Spain $\left(76.4\right.$ ton ha $\left.{ }^{-1}\right)$, and Turkey (35.8 ton $\left.\mathrm{ha}^{-1}\right)$. Productivity is highly constrained by several factors in Tigray and other parts of Ethiopia. One of the contributing factors to this low yield is suboptimal fertilizer use by tomato growers (Edosa et al. 2013, Balemi, 2008; Lemma, 1992). In particular, $\mathrm{N}$ and $\mathrm{P}$ are major nutrients deficient in almost all soils of the cultivated area of Tigray.

In Ethiopia, the depletion rates of $\mathrm{N}, \mathrm{P}$ and $\mathrm{K}$ are 122,13 , and $82 \mathrm{~kg} \mathrm{~N} \mathrm{ha}^{-1} 1$ year ${ }^{-1}$, respectively, which are more severe in highland areas (Haileslassie et al., 2005), such as Tigray. Soil fertility loss is related to cultural practices such as low fertilizer use, removal of vegetative cover (such as straw or stubble), and burning plant residues or the annual burning of vegetation on grazing land (Endale, 2011). More than $50 \%$ of the soil in Tigray is deficient in macro essential nutrients (ATA, 2014). Despite the deficiency, $N$ and $\mathrm{P}$ fertilizer applications for vegetable crops such as tomato are limited and are expressed in low yields. This is more noticeable in the highland areas of Tigray as soil erosion is severe.

Tomatoes are considered "heavy feeders" because of their rapid growth and long production season, making the crop highly sensitive to soil fertility. To obtain one ton of fresh fruit, the plant needs to absorb on average $2.5-3 \mathrm{~kg} \mathrm{~N}, 0.2-0.3 \mathrm{~kg} \mathrm{P}$, and $3-3.5 \mathrm{~kg} \mathrm{~K}$ (Hedge, 1997). In addition, P, the second most important plant growth-limiting nutrient after $\mathrm{N}$, is abundantly available in soils in both organic and inorganic forms (Khan et al., 2009). Despite a large reservoir of $P$, the amount of available forms to plants is generally low. Plants are unable to utilize phosphate because $95-99 \%$ phosphate is present in the insoluble, immobilized, and precipitated form (Pandey et al., 2007).

It is well documented that $\mathrm{N}$ and $\mathrm{P}$ application enhances the yield and yield-related traits of tomato (Edosa et al., 2013). It also affects the quality of fruits (Ronga et al., 2020). However, optimum N and P rate effects varied with variety, soil type, season, climatic condition, and other management practices. Specific agronomic protocols and extension services are required to optimally manage tomato crop systems (Ronga et al., 2020). The required amount of nutrient determination is vital for optimum plant growth and development without posing unnecessary expenditure, related negative health, and environmental effects. The soil in the Hawzen district is low in total nitrogen $(0.05 \%)$ and available $P$ (5.45 ppm) (Tekalign, 1991). However, limited literature exists on the $\mathrm{N}$ and $\mathrm{P}$ rate determination in the district. Although the producers are using the national recommendation with an amount of $\mathrm{N}$ and $\mathrm{P}$, an 
optimum amount of fertilizers varies with genetic potential/responses of varieties in use, microclimate and edaphic factors, the market of the input and product. Hence, this study helps generate information on the effects of $\mathrm{N}$ and $\mathrm{P}$ on tomato fruit yield and yield-related components, quality and biochemical composition in Hawzen, Eastern Tigray.

\section{Material And Methods}

\subsection{Description of the Study Area}

The trial was conducted in Hawzen district, Tigray Ethiopia, specifically at the Hayelom site (Fig. 1). Hawzen is located at $39^{\circ} 27^{\prime} 2^{\prime \prime} \mathrm{E}$ and $13^{\circ} 15^{\prime} 16^{\prime \prime} \mathrm{N}$, an altitude of 2120 meters above sea level. The longterm average (1971-2000) annual precipitation is $536 \mathrm{~mm}$, while the total rainfall of the growing season is $469 \mathrm{~mm}$. The average minimum temperature was $10^{\circ} \mathrm{C}$, and the maximum temperature was $27^{\circ} \mathrm{C}$.

\subsection{Experimental Treatments, Design, and Procedure}

The treatments consisted of four rates of $N\left(0,69,138\right.$ and $\left.207 \mathrm{~kg} \mathrm{~N} \mathrm{ha}^{-1}\right)$ and four rates of $\mathrm{P}(0,46,69$ and $92 \mathrm{P}_{2} \mathrm{O}_{5} \mathrm{ha}^{-1}$ ) laid out in a randomized complete block design with three replications. Tomato var. Miya (semi-determinate type) seed, $\mathrm{N}$ fertilizer in the form of urea $(46 \% \mathrm{~N})$ and phosphate fertilizer in the form of $\mathrm{P}_{2} \mathrm{O}_{5}$ were used for the study.

The whole amount of $\mathrm{P}$ fertilizer was applied to the experimental plots three days before transplanting. $\mathrm{N}$ was applied three times as the $1 / 2$ amount was at the time of transplanting, one fourth $(1 / 4)$ at the midgrowth stage (35 days after transplanting) and one fourth (1/4) at early flowering. The size plot was $3 \mathrm{~m} \mathrm{x}$ $3 \mathrm{~m}\left(9 \mathrm{~m}^{2}\right)$, and the distance between the plots and blocks was $1 \mathrm{~m}$ and $1.5 \mathrm{~m}$ apart, respectively. The spacing between rows and plants was $75 \mathrm{~cm}$ and $30 \mathrm{~cm}$, respectively. The land was plowed to a fine tilth by repeated harrowing and leveling using oxen and labor force. Recommended raised seedbeds of $5 \mathrm{~m}$ in length and $1 \mathrm{~m}$ in width were prepared near the experimental site to reduce transplanting shock during transplanting time. Seedlings were transplanted four weeks after sowing, where seedlings attained 2-3 true leaf stages.

\subsection{Data Collection Procedures}

\subsubsection{Soil sampling procedure and physico-chemical characterization}

Composite surface soil samples (0-30 cm depth) were collected randomly in a zig-zag pattern from ten sampling spots of the entire experimental site before planting for the determination of selected physicochemical properties of the soil. Soil texture was determined using the Boyoucous hydrometer method (Bouyoucos, 1965). Soil pH (McLean, 1982) was determined from a suspension of 1:2.5 of the soil:water ratio using a glass electrode attached to a digital $\mathrm{pH}$ meter. The organic carbon was determined by the dichromate oxidation method and subsequent titration with ferrous ammonium sulfate (Walkley and 
Balck, 1934), and \% of organic matter (OM) was obtained by multiplying \% OC by 1.74 assuming that the average $\mathrm{C}$ concentration of organic matter is $58 \%$. The total soil nitrogen was estimated using the Kjeldahl procedure. The determination of available phosphorus was carried out following the Olsen extraction method (Olsen et al., 1954). Exchangeable bases (K, Ca, Mg, and $\mathrm{Na}$ ) and cation exchange capacity were determined by the leaching method with ammonium acetate solutions ( $\left.1 \mathrm{M} \mathrm{NH}_{4} \mathrm{OAc}\right)$. The concentrations of exchangeable $\mathrm{Ca}$ and $\mathrm{Mg}$ were measured from the extract with an atomic spectrophotometer, while exchangeable $\mathrm{K}$ and $\mathrm{Na}$ were measured with a flame photometer (Van Reeuwijk, 2002).

\subsubsection{Crop-related data}

Yield- and yield-related attributes: Plant height $(\mathrm{cm})$ was determined with the use of the tape rule measured from the base of the plant above the ground to the last expanded leaf of the growing tip. The leaf area index, number of branches per plant and number of flower clusters were collected. The number of clusters per plant, number of fruits per cluster, and average number of fruits per plant were recorded. The average fruit weight per plant $(\mathrm{kg})$, marketable fruit weight (ton ha- ${ }^{-1}$ ), and fruit yield per hectare (ton $\mathrm{ha}^{-1}$ ) were recorded.

Fruit quality analysis: Well-ripened fruits were collected, washed, dried, sliced, and homogenized. Quality parameters such as titratable acidity expressed as the percentage of citric acid, total soluble solids measured using a hand refractometer at $0-32^{\circ} \mathrm{Brix}$ value and sugar to acid ratio were computed (Waskar et al., 1999). The ascorbic acid content of fruits was analyzed using the method of AoAC (1995). Lycopene content was estimated from the absorbance measurement at $503 \mathrm{~nm}$ UV-spectrophotometer (Lime et al., 1957). The sample plant tissue was dried at $65^{\circ} \mathrm{C}$ until a constant weight was obtained and ground and sieved for the determination of tissue $\mathrm{N}$ and $\mathrm{P}$ content.

\subsection{Statistical Analysis}

Data were subjected to analysis of variance (ANOVA) using Statistical Analysis System (SAS), version 9.2 (2009). Detection of differences among treatment means for significance was done using least significant difference (LSD) at the 0.05 probability level.

\section{Result And Discussion}

\subsection{Soil chemical and physical characteristics of the experimental site}

The physical and chemical properties of the soils of the experimental fields before planting are indicated in Table 1. The analytical results indicated that the particle size distribution of the surface soil $(0-20 \mathrm{~cm})$ of the experimental sites was dominated by clay, with a proportion of $69 \%$ sand, $14.4 \%$ silt, and $16.6 \%$ clay in the Hawzen district. 
Table 1

Physical and chemical properties of the soil before transplanting

\begin{tabular}{|c|c|c|}
\hline Parameters & Values & Rate \\
\hline Sand (\%) & 68 & \\
\hline Silt (\%) & 15 & \\
\hline Clay (\%) & 17 & \\
\hline Textural class & Sandy loam & \\
\hline $\mathrm{pH}(1: 2.5 \mathrm{H} 20)$ & 6.25 & Slightly acidic \\
\hline $\mathrm{OM}(\%)$ & 1.1 & Low \\
\hline TN (\%) & 0.083 & Low \\
\hline Available $\mathrm{P}\left(\mathrm{mg} \mathrm{Pkg}^{-1}\right)$ & 6.15 & Low \\
\hline CEC (cmolc kg ${ }^{-1}$ ) & 18.53 & Very high \\
\hline Exchangeable $\mathrm{Na}\left(\mathrm{cmol}(+) \mathrm{kg}^{-1}\right.$ & 0.1 & low \\
\hline Exchangeable $\mathrm{K}\left(\mathrm{cmol}(+) \mathrm{kg}^{-1}\right.$ & 0.3 & Moderate \\
\hline Exchangeable $\mathrm{Ca}\left(\mathrm{cmol}(+) \mathrm{kg}^{-1}\right.$ & 6.5 & Moderate \\
\hline Exchangeable $\mathrm{Mg}\left(\mathrm{cmol}(+) \mathrm{kg}^{-1}\right.$ & 4.0 & High \\
\hline Percentage of base saturation & 58.82 & Moderate \\
\hline
\end{tabular}

Hence, the experiment had a sandy loam, textural class. The $\mathrm{pH}$ of the soil was 6.25 , showing that the nature of the soil was slightly acidic (Bruce and Rayment, 1982), which is in the range of productive soils. The available $P$ was $6.15 \mathrm{mg} \mathrm{kg}^{-1}$ before planting in Hawzen. According to the Holford and Cullis (1985) classification, soils with available $P$ contents $<25 \mathrm{mg} \mathrm{kg}^{-1}$ are rated as very high, $10-17 \mathrm{mg} \mathrm{kg}^{-1}$ are moderate, $5-10 \mathrm{mg} \mathrm{kg}^{-1}$ as low and $<5 \mathrm{mg} \mathrm{kg}^{-1}$ as very low. Hence, the soil grouped under a medium level. Soil with OM values within 1.70 to $3.0 \%$ is rated as moderate (Charman and Roper, 2007). Accordingly, the experimental soil in the area has a value of $1.1 \%$, which is rated as low in OM. More importantly, total $\mathrm{N}$ in the experimental area was found to be $0.08 \%$ in Hawzen, which is a low rate according to Bruce and Rayment (1982). The soil analysis result of the experimental area indicated that the CEC values of soils were $18.5 \mathrm{cmolc} \mathrm{kg}^{-1}$ in the experimental site, showing high rate values (Hazelton and Murphy, 2007). The experimental soil has medium levels of exchangeable $\mathrm{K}$, moderate exchangeable $\mathrm{Ca}^{2+}$, low exchangeable $\mathrm{Na}^{+}$, and high exchangeable $\mathrm{Mg}^{2+}$ (Metson, 1961) (Table 1). The base saturation of the soil is moderate (58.8\%) and satisfactory for tomato production (Metson, 1961). 


\subsection{Effects of $\mathrm{N}$ and $\mathrm{P}$ on the growth performance of tomato}

Plant height: The results showed that plant height was significantly $(p<0.01)$ affected by different rates of $\mathrm{N}$ and $\mathrm{P}$ (Table 2a). Nevertheless, the interaction effects of $\mathrm{N}$ and $\mathrm{P}$ showed non-significant $(\mathrm{p}<0.05)$ effects (Table 2a). Using $N$ at rates of 69,138 , and $207 \mathrm{~kg} \mathrm{ha}^{-1}$ increased the plant height of tomato by $12.1 \%, 19.5 \%$, and $31.2 \%$ compared to the control (Fig. 2). This might be due to $\mathrm{N}$ fertilizer ensuring favorable conditions for the elongation of stems with optimum vegetative growth. Other researchers also reported that too little N in the soil stunts plant growth (Etissa et al., 2013; Mary, 2006; Sainju et al. 2003).

Table 2a

Results of analysis of variance of plant height, number of primary branches, number of fruit clusters per plant, number of flower clusters per plant, number of fruits per cluster, marketable fruit yield, total fruit yield, mean fruit weight

\begin{tabular}{|c|c|c|c|c|c|c|c|c|c|c|}
\hline sV & $\mathrm{PH}$ & LAI & NPB & NFC & NFrC & $\mathrm{NF} / \mathrm{C}$ & $\begin{array}{l}\text { MFY (ton } \\
\mathrm{ha}^{-1} \text { ) }\end{array}$ & $\begin{array}{l}\text { TFY (ton } \\
\mathrm{ha}^{-1} \text { ) }\end{array}$ & $\begin{array}{l}\text { MFW } \\
(\mathrm{g})\end{array}$ & $\begin{array}{l}\text { FL } \\
(\mathrm{cm})\end{array}$ \\
\hline $\mathbf{N}$ & ** & $\star *$ & $\star \star$ & $\star \star$ & $\star \star$ & $\star \star$ & $\star \star$ & $\star *$ & $\star *$ & $\star \star$ \\
\hline$P$ & * & * & $\star \star$ & $\star \star$ & $\star \star *$ & $\star \star$ & $\star \star$ & $\star \star$ & $\star \star *$ & $\star \star$ \\
\hline$N \star P$ & ns & ns & ns & ns & ns & ns & * & * & $\star \star$ & * \\
\hline CV & 15 & 5.8 & 12.6 & 15.3 & 4.75 & 24.32 & 17.33 & 16.55 & 5.49 & 10.31 \\
\hline
\end{tabular}

Table 2a

Results of analysis of variance of total soluble solid (TSS), total sugar, titratable acidity (TA), ascorbic acid content, lycopene content $\mathrm{N}$ and $\mathrm{P}$

\begin{tabular}{|c|c|c|c|c|c|c|c|}
\hline $\begin{array}{l}\text { Source of } \\
\text { variation }\end{array}$ & $\begin{array}{l}\text { TSS } \\
\text { ( }{ }^{\circ} \text { Brix) }\end{array}$ & $\begin{array}{l}\text { Total } \\
\text { sugar }\end{array}$ & TA & $\begin{array}{l}\text { Ascorbic } \\
\text { acid }\end{array}$ & $\begin{array}{l}\text { Lycopene } \\
\text { content (mg } \\
\mathrm{g}^{-1} \text { ) }\end{array}$ & $\begin{array}{l}\mathrm{N}(\mathrm{mg} \\
\left.\mathrm{g}^{-1}\right)\end{array}$ & $\begin{array}{l}P(m g \\
\left.g^{-1}\right)\end{array}$ \\
\hline $\mathbf{N}$ & $\star \star *$ & * & * & $\star \star *$ & ns & ** & ns \\
\hline$P$ & $\star \star$ & $\star \star$ & $\star \star$ & $\star \star$ & ns & $\star \star$ & $\star \star$ \\
\hline$N * P$ & ns & ns & ns & ns & ns & ns & ns \\
\hline CV & 15.09 & 13.89 & 19.98 & 17.86 & 25 & 3.0 & 21.17 \\
\hline
\end{tabular}

TSS = total soluble solids, TA = titratable acidity, $*$ **, ns F-test significant at $p<0.05, p<0.01$, and not significant, respectively 
Similar to the $\mathrm{N}$ rate, the application of 46,69 , and $92 \mathrm{~kg} \mathrm{Pha}^{-1}$ produced taller plants compared to the control by $8.8 \%, 13.04 \%$, and $16.5 \%$, respectively (Fig. 2). Increasing the P level increased the plant height linearly. In line with this, Singh and Sangama (2000) suggested that P is a constituent of nucleoprotein, known to play a leading role in photosynthesis, cell division, and tissue formation, which may contribute to plant height.

Leaf area index (LAl): The results revealed that a significant $(p<0.05)$ increasing trend in LAl was recorded with increasing applied $\mathrm{N}$ and $\mathrm{P}$, but their interaction effects were non-significant (Table 2a). Increasing $\mathrm{N}$ rates resulted in increasing LAl and widest leaf recorded at the highest rate of N (Fig. 2). Similarly, Tie et al. (2002) reported a sharp increase in LAl in response to the application of $\mathrm{N}$ fertilizer. $\mathrm{N}$ is necessary for photosynthesis, the formation of chlorophyll and nucleic acids in which its absence or deficiency causes stunted growth (Tisdale et al., 2003). Similarly, as applied P increased, there was an increase in LAl widest recorded at $92 \mathrm{~kg} \mathrm{ha}^{-1}$ but similar to $69 \mathrm{~kg} \mathrm{ha}^{-1}$ (Fig. 2). Similarly, Khavarinejad et al. (2009) reported that a low phosphate supply reduced leaf area in P-deficient plants. Phosphate deficiency causes a negative effect on leaf cell expansion, which is the result of carbohydrate deficiency (Louw-Gaume et al., 2010).

Primary branches: The results revealed that the rates of $\mathrm{N}$ and $\mathrm{P}$ significantly $(\mathrm{p}<0.05)$ influenced the number of primary branches per plant. However, their interaction resulted in non-significant $(p<0.01)$ effects (Table 2a). Nil fertilizer treatment resulted in the lowest branch compared to the other treatments of $\mathrm{N}$ and $\mathrm{P}$, whereas no more increase in a primary branch was detected when $\mathrm{N}$ was applied beyond the rate of $69 \mathrm{~kg} \mathrm{ha}^{-1}$ (Fig. 3). $\mathrm{N}$ supply enhanced the tomato branch, which could be due to the positive impact stimulation of meristematic growth and the new branches and leaves. Similar to this, Rao et al. (2014) reported that increasing $\mathrm{N}$ assisted chloroplast function, thus increasing the growth of a plant.

An increase in the primary branch was observed with increasing $P$ rate. Application of $P$ at rates of 92,69 and $46 \mathrm{~kg}$ ha increased lateral branches by $44.3 \%, 34.4 \%$, and $19.4 \%$, respectively, compared to the control (Fig. 3). This may support the fact that $P$ encourages the formation of ATP and supplies energy for new cell formation, which may help to form new branches. In contrast, Etissa et al. (2013) reported that the application of P did not affect a number of lateral branches of cv. Melkashola under vertisols. The inconsistent results could be due to the variation in soil physical and chemical properties and cultivars.

Flower and fruit number per cluster: The results revealed that the number of flower clusters was significantly $(p<0.01)$ influenced by different rates of $N$ and P. However, no significant influence was observed due to the interaction of $\mathrm{N}$ and $\mathrm{P}$ (Table 2a). The lowest number of flower and fruit clusters was recorded in the control treatment compared with any other plots that received additional $\mathrm{N}$ fertilizer. This could be because $\mathrm{N}$ helps chlorophyll formation, which helps photosynthesis. Similar to this suggestion, Lu and Zhang (2000) also reported that $\mathrm{N}$ deficiency decreases the quantum yield of photosystem II, the electron transport system, and the maximum photochemical efficiency of photosystem II. Similarly, the highest and lowest flower and fruit clusters were obtained from $92 \mathrm{~kg} \mathrm{Pha}^{-1}$ and the control, respectively 
(Fig. 3). An increase in flower clusters per plant was observed with an extra addition of P. The maximum cluster number could be due to the effects of $\mathrm{P}$ in promoting blossom bud formation.

\subsection{Effects of $\mathbf{N}$ and $\mathrm{P}$ on fruit yield}

Mean fruit weight and fruit length: ANOVA results demonstrated that the individual effects of $N, P$, and their interaction showed significant $(p<0.01)$ effects on mean fruit weight and fruit length (Table 3$)$. Mean fruit weight and fruit length showed the highest values due to applications of $138 \mathrm{~kg} \mathrm{P} \mathrm{ha}^{-1}$ and $92 \mathrm{~kg} \mathrm{Pha}^{-1}$ (Table 3). Roy et al. (2011) also reported that the average fruit weight increased in capsicum. Generally, at low rates of $N$ and $P$, the average fruit weight and fruit length were low. The positive response shown by yield parameters to $\mathrm{N}$ and $\mathrm{P}$ could be directly linked to the well-developed photosynthetic surfaces and increased physiological activities leading to more assimilates being produced and subsequently translocation of assimilates and utilized for fast fruit development.

Marketable and total fruit yield: Significant N and P $(p<0.01)$ interactions $(p<0.05)$ were noted for marketable fruit yield and total fruit (Table 3). The lowest values of marketable and total fruit yield were obtained from the control treatment. The highest values of marketable and total fruit yield were highest with the treatments of 138 and $92 \mathrm{~kg} \mathrm{ha}^{-1}$ (Table 3). This could also be due to the individual mean fruit weight increment. Similar to the current findings, Balemi (2008) also reported the highest fruit yield obtained from the highest rate and lowest from the lowest rate of NP. The nutrient requirement of the tomato is an important factor if large quantities of high-quality fruits are to be produced effectively and efficiently (Anderson et al., 1999). Higher yields at high levels of $\mathrm{N}$ and $\mathrm{P}$ are due to better fertilizer responsiveness of the tomato crop (Mishra et al., 2004). 
Table 3

Effects of $\mathrm{N}$ and $\mathrm{P}$ on marketable, total fruit yield, mean fruit weight and fruit length of tomato under Hawzen conditions

\begin{tabular}{|c|c|c|c|c|}
\hline $\begin{array}{l}\mathrm{N}: \mathrm{P} \\
\left(\mathrm{kgha}^{-1}\right)\end{array}$ & $\begin{array}{l}\text { Mean fruit } \\
\text { weight (g) }\end{array}$ & $\begin{array}{l}\text { Fruit length } \\
(\mathrm{cm})\end{array}$ & $\begin{array}{l}\text { Marketable fruit yield (ton } \\
\mathrm{ha}^{-1} \text { ) }\end{array}$ & $\begin{array}{l}\text { Total fruit yield (ton } \\
\mathrm{ha}^{-1} \text { ) }\end{array}$ \\
\hline $0: 0$ & $47.00^{\mathrm{h}}$ & $3.67^{h}$ & $16.33^{\mathrm{h}}$ & $17.87^{\mathrm{g}}$ \\
\hline $0: 46$ & $49.67^{\mathrm{gh}}$ & $4.67^{\mathrm{efg}}$ & $27.00^{\mathrm{fg}}$ & $28.87^{\text {ef }}$ \\
\hline $0: 69$ & $54.00^{\mathrm{gh}}$ & $4.67^{\text {efg }}$ & $29.33^{\text {def }}$ & $31.00^{\text {de }}$ \\
\hline $0: 92$ & $53.67^{\mathrm{fg}}$ & $5.33^{\mathrm{cde}}$ & $28.67^{\mathrm{defg}}$ & $30.50^{e}$ \\
\hline 69:0 & $49.67^{\mathrm{gh}}$ & $4.00^{\mathrm{gh}}$ & $19.00^{\mathrm{gh}}$ & $20.37^{\mathrm{fg}}$ \\
\hline $69: 46$ & $54.33^{\mathrm{gh}}$ & $5.00^{\text {def }}$ & $31.00^{\text {def }}$ & $32.50^{\text {cde }}$ \\
\hline $69: 69$ & $58.33^{\mathrm{gh}}$ & $5.33^{\text {cde }}$ & $32.33^{\text {def }}$ & $34.00^{\text {cde }}$ \\
\hline 69:92 & $63.33^{\mathrm{bcd}}$ & $6.00^{a b c}$ & $38.33^{\mathrm{bcd}}$ & $40.33^{\mathrm{bcd}}$ \\
\hline $138: 0$ & $51.00^{\mathrm{gh}}$ & $4.33^{\mathrm{fgh}}$ & $30.33^{\text {def }}$ & $31.83^{\text {cde }}$ \\
\hline $138: 46$ & $60.00^{\text {cde }}$ & $5.00^{\text {def }}$ & $31.33^{\text {def }}$ & $32.83^{\mathrm{cde}}$ \\
\hline 138:69 & $65.00^{b c}$ & $5.33^{\text {cde }}$ & $42.67^{b c}$ & $45.17^{b}$ \\
\hline 138:92 & $73.33^{a}$ & $6.67^{a}$ & $55.33^{a}$ & $57.00^{a}$ \\
\hline $207: 0$ & $51.33^{\mathrm{gh}}$ & $4.67^{\mathrm{efg}}$ & $28.00^{\text {efg }}$ & $29.83^{\mathrm{ef}}$ \\
\hline 207:46 & $56.67^{b}$ & $5.67^{b c d}$ & $33.00^{\text {cdef }}$ & $34.33^{\mathrm{cde}}$ \\
\hline 207:69 & $67.67^{a b}$ & $6.33^{\mathrm{ab}}$ & $46.00^{\mathrm{ab}}$ & $48.00^{\mathrm{ab}}$ \\
\hline 207:92 & $65.00^{\mathrm{bc}}$ & $5.33^{\mathrm{cde}}$ & $38.00^{\text {bcde }}$ & $41.00^{b c}$ \\
\hline LSD & 5.18 & 0.93 & 9.70 & 9.5 \\
\hline
\end{tabular}

\subsection{Effects of $\mathbf{N}$ and $\mathrm{P}$ on fruit chemical composition}

Total soluble solids (TSS): A significant difference in TSS was observed among different rates of $\mathrm{N}$ and $\mathrm{P}$ but not due to their interactions (Table 2b). Except for the control treatments, no difference in TSS values was detected under different rates of N, and the lowest value of TSS was recorded in the control 
(Table 4). Similarly, TSS contents increased with P applications, and the lowest values were observed in the control. $\mathrm{N}$ is a constituent of protein, and amino acids directly affect the TSS (Kirimi et al., 2011). Other researchers also reported that soluble solids decreased with decreased N (Kuscu et al. 2014; Simonne et al. 2007). Conversely, Ronga et al. (2020) and Warner et al. (2004) reported that $\mathrm{N}$ had no effects on the TSS of tomato.

Table 4

Fruit total soluble solid (TSS), total sugar, titratable acidity (TA), protein, ascorbic acid, lycopene content, and $\mathrm{P}$ content of tomato fruits as influenced by different rates of $\mathrm{P}$ and $\mathrm{N}$ at Hawzen

\begin{tabular}{|lllllllll}
\hline Factors & Treatments & $\begin{array}{l}\text { TSS } \\
\text { ('Brix) }\end{array}$ & $\begin{array}{l}\text { Total } \\
\text { sugar }\end{array}$ & TA & $\begin{array}{l}\text { Ascorbic } \\
\text { acid }\end{array}$ & $\begin{array}{l}\text { Lycopene } \\
\text { content } \\
\left(\mathrm{mgg}^{-1}\right)\end{array}$ & $\begin{array}{l}\left.{ }^{1}\right) \\
\mathrm{N}^{\prime} \mathrm{mgg}^{-}\end{array}$ & $\begin{array}{l}\mathrm{P}\left(\mathrm{mg} / \mathrm{g}^{-}\right. \\
1\end{array}$
\end{tabular}

$\mathrm{N}(\mathrm{kg} / \mathrm{ha})$

\begin{tabular}{llllllll}
0 & $5.26^{\mathrm{b}}$ & $4.00^{\mathrm{b}}$ & $0.37^{\mathrm{b}}$ & $8.25^{\mathrm{c}}$ & $0.05^{\mathrm{b}}$ & $0.31^{\mathrm{b}}$ & 7.5 \\
\hline 69 & $6.40^{\mathrm{a}}$ & $4.38^{\mathrm{ab}}$ & $0.36^{\mathrm{b}}$ & $9.33^{\mathrm{bc}}$ & $0.06^{\mathrm{ab}}$ & $0.33^{\mathrm{a}}$ & 7.6 \\
\hline 138 & $7.02^{\mathrm{a}}$ & $4.63^{\mathrm{a}}$ & $0.41^{\mathrm{ab}}$ & $10.25^{\mathrm{ab}}$ & $0.07^{\mathrm{a}}$ & $0.34^{\mathrm{a}}$ & 8.33 \\
\hline 207 & $7.08^{\mathrm{a}}$ & $4.85^{\mathrm{a}}$ & $0.46^{\mathrm{a}}$ & $11.58^{\mathrm{a}}$ & $0.07^{\mathrm{a}}$ & $0.34^{\mathrm{a}}$ & 7.33 \\
\hline LSD & $\mathbf{0 . 8}$ & $\mathbf{0 . 5 2}$ & $\mathbf{0 . 0 7}$ & $\mathbf{1 . 4 7}$ & $\mathbf{0 . 0 1}$ & $\mathbf{0 . 0 0 8}$ & $\mathbf{1 . 3 6}$
\end{tabular}

$\mathrm{P}(\mathrm{kg} / \mathrm{ha})$

\begin{tabular}{llllllll}
0 & $4.91^{\mathrm{c}}$ & $3.60^{\mathrm{b}}$ & $0.34^{\mathrm{b}}$ & $8.25^{\mathrm{c}}$ & 0.005 & 0.3 & $5.75^{\mathrm{c}}$ \\
\hline 46 & $6.20^{\mathrm{b}}$ & $4.00^{\mathrm{b}}$ & $0.38^{\mathrm{b}}$ & $9.33^{\mathrm{bc}}$ & 0.061 & 0.33 & $7.41^{\mathrm{b}}$ \\
\hline 69 & $7.15^{\mathrm{a}}$ & $5.00^{\mathrm{a}}$ & $0.40^{\mathrm{b}}$ & $10.25^{\mathrm{ab}}$ & 0.072 & 0.33 & $8.17^{\mathrm{ab}}$ \\
\hline 92 & $7.50^{\mathrm{a}}$ & $5.25^{\mathrm{a}}$ & $0.48^{\mathrm{a}}$ & $11.58^{\mathrm{a}}$ & 0.070 & 0.34 & $9.42^{\mathrm{a}}$ \\
\hline LSD & $\mathbf{0 . 8 1}$ & $\mathbf{0 . 5 1}$ & $\mathbf{0 . 0 6}$ & $\mathbf{1 . 4 7}$ & $\mathbf{0 . 0 1}$ & 0.008 & $\mathbf{1 . 3 6}$ \\
\hline
\end{tabular}

Total sugar content: The results demonstrated that the total sugar content of fruits was significantly $(p<$ 0.05) affected by different rates of $\mathrm{N}$ and $\mathrm{P}$. However, the interaction effects of $\mathrm{N}$ and $\mathrm{P}$ were not significant (Table 4$)$ and did not affect the total sugar content $(p<0.05)$. The lowest total sugar content was obtained in the nil fertilizer rate (Table 4). Likewise, the application of 69 and $92 \mathrm{~kg} \mathrm{Pha}^{-1}$ showed higher total sugar compared to the control and $46 \mathrm{~kg} \mathrm{P} \mathrm{ha}^{-1}$. Total soluble contents are an indicator of mineral nutrient concentration in fruit, and these values generally increase with fertilization (Kirimi et al., 2011). The sugar to TSS ratio reached the highest value at $50 \mathrm{~kg} \mathrm{ha}^{-1} \mathrm{~N}$ supply compared to below and above these levels (Ronga et al., 2020). Sainju et al. (2003) also reported that $\mathrm{N}$ deficiency reduced tomato taste. Wang et al. (2007) reported that sugar increased due to increasing N supply. 
Ascorbic acid: $\mathrm{N}$ and $\mathrm{P}$ rates did significantly affect vitamin $\mathrm{C}$ in tomato fruit. Nevertheless, the interaction effects of $\mathrm{N}$ and $\mathrm{P}$ were nonsignificant in both traits (Table 4). As shown in Table 4, the vitamin $\mathrm{C}$ content of tomato fruits increased with increasing amounts of $\mathrm{N}$ and $\mathrm{P}$ fertilizer added. However, only the control treatment showed the lowest vitamin $\mathrm{C}$ content in the fruits. Similar to the current findings, Taiwo et al. (2007) reported that the control had the lowest vitamin C content. Conversely, Dumas et al. (2003) and Simonne et al. (2007) recommend a low rate of $\mathrm{N}$ to obtain a high ascorbic acid level. This indicated that a higher concentration of $\mathrm{P}$ in the soil can increase the content of vitamin $\mathrm{C}$.

Titratable acidity (TA): Significant variation in TA was shown due to $N$ and $P$ rates but not their interaction (Table 4). The control treatment had the lowest TA value compared to $138 \mathrm{~kg} \mathrm{ha}^{-1}$, but further, an increase in $\mathrm{N}$ supply beyond $138 \mathrm{~kg} \mathrm{ha}^{-1}$ did not increase the TA of the fruit. Other studies also reported that TA increased with increasing $N$ supply (Wang et al., 2007; Kuscu et al., 2014) also reported increasing TA with increasing $N$ rate, and Taiwo et al. (2007) reported that the control had the lowest TA. In the case of the $P$ rate, an increasing trend was shown with the increasing rate but did

Lycopene Content: The application of $\mathrm{N}$ significantly $(\mathrm{p}<0.05)$ increased the lycopene content of tomato fruits. An increasing trend occurred when $N$ was added th the rate of $69 \mathrm{~kg}$ ha and became significant at $138 \mathrm{~kg} \mathrm{ha}^{-1}$ compared to the control (Table 4). Lycopene is an important trait in tomato, accounting for $90 \%$ of carotenoids (Dumas et al., 2003). Correspondingly, Simonne et al. (2007) also reported increased $\beta$-carotene with increasing $N$ rate. Adequate nutrient availability is vital for the production and nutrient content of tomatoes (Sainju et al., 2003). However, different rates of $\mathrm{P}$ and the interaction between $\mathrm{N}$ and $P$ were not significant $(p<0.05)$ for lycopene content (Table 4). Conversely, others reported that increased concentrations of $P$ in the soil increased lycopene content in tomato fruits (Zdravković et al. 2007; Dumas et al. 2002). Thus, the results indicated that the lycopene content of tomato fruit could respond in different ways to individual fertilizer depending on variety, soil condition, environmental factors, and other management practices.

$\mathrm{N}$ concentration: $\mathrm{P}$ fertilization did not affect fruit $\mathrm{N}$ concentration. However, the $\mathrm{N}$ concentration of fruits was significantly $(p<0.05)$ influenced by $\mathrm{N}$ fertilization (Table $2 \mathrm{a})$. The lowest $\mathrm{N}$ concentration of fruits was recorded from the control treatment (Table 4). However, there was no further variation as much increase in the rate of $\mathrm{N}$. High nitrogen application can increase fruit $\mathrm{N}$ concentration, which indicates variable $\mathrm{N}$ effects due to the corresponding applied amount. Hormonally, Santamaria (2006) reported that fresh fruit tomato is classified as a very low-nitrate accumulating vegetable. This may be the reason for the similar $\mathrm{N}$ concentrations recorded in the different rates of $\mathrm{N}$ fertilizer except the control treatment.

P concentration: The $P$ content of fruits was significantly $(p<0.01)$ affected by the application of $P$ fertilizer added at different rates. However, neither levels of $N$ nor the interaction between $N$ and $P$ resulted in a significant $(p<0.05)$ effect on the $P$ content of fruit $(T a b l e ~ 2 b)$. With increasing $P$ rates, an increase in the $P$ content of tomato fruit was recorded. The highest value of $P$ content was recorded from the rate of $92 \mathrm{~kg} \mathrm{Pha}^{-1}$, and the lowest was recorded with the control treatment (Table 4). Similar to this finding, Gill and Verma (2018) reported that P uptake increased with increased NPK levels, and they suggested that it 
can be due to improved absorption and utilization of $\mathrm{P}$ at higher rates of application. In fact, fruit mineral composition can vary due to the response of cultivars to fertilizer application. Conversely, fruit $P$ composition decreased with increasing rates of $\mathrm{N}$ (Ronga et al., 2020). This could vary due to climatic conditions, soil types, and time of application.

\section{Conclusion}

The application of $\mathrm{N}$ and $\mathrm{P}$ increased plant height, leaf area index, number of primary branches per plant, number of clusters per plant, number of flower clusters, number of fruit per clusters, and fruit set. The interaction of $\mathrm{N}$ and $\mathrm{P}$ rates had significant effects on marketable, total fruit yield, mean fruit weight, and fruit length. Likewise, the main effects of $\mathrm{N}$ and $\mathrm{P}$ rates were remarkable on total soluble solids, total sugar, titratable acidity, ascorbic acid, lycopene content, and protein. A significant influence on the $\mathrm{P}$ content of tomato was detected due to varied rates of $\mathrm{P}$ but not $\mathrm{N}$ and its interaction with $\mathrm{P}$. Fruit $\mathrm{N}$ concentration was significantly influenced by $\mathrm{N}$ rates only. Application of $\mathrm{N}$ and $\mathrm{P}$ at rates of 138 and 69 showed the highest values in most growth, yield and quality parameters recorded, although similar to the higher rats of both treatments. Overall, producers can use $138 \mathrm{~kg} \mathrm{Nha}^{-1}$ and $69 \mathrm{~kg} \mathrm{Pha}^{-1}$ in Hawzen, Northern Ethiopia.

\section{Declarations}

\section{Ethics approval and consent to participate}

No ethics approval or consent to participate was needed for any part of this study.

\section{Consent for publication}

The author has reviewed and approved the manuscript for submission.

\section{Competing interests}

The authors declare no conflicts of interest.

\section{Funding}

This research was funded by Adigrat University with grant No. ADU/CAES/051/10.

\section{Availability of data}

Additional supporting data can be found from corresponding author of this research Hailay Gebremedhin 


\section{Author contribution}

Hailay initiated the idea, and all of the authors designed the experiments and carried out the data collection and analysis. All authors also read, revised and approved the final manuscript.

\section{Acknowledgments}

The authors would like to thank Hwazen district an Agriculture Office and Haylom Kebele for their overall support in conducting the research and Adigrat University for funding.

\section{References}

1. Andersen, P. C., Rhoads, F. M., Olson, S. M., \& Brod beck, B. V. (1999). Relationships of nitrogenous compounds in petiole sap of tomato to nitrogen fertilization and the value of these compounds as a predictor of yield. HortScience, 34(2), 254-258. https://doi.org/10.21273/HORTSCI.34.2.254

2. Balemi, T. (2008). Response of tomato cultivars differing in growth habit to nitrogen and phosphorus fertilizers and spacing on vertisol in Ethiopia. Acta agriculturae slovenica, 91(1), 103-119. https://10.2478/v10014-008-0011-8

3. Bouyoucos G. Hydrometer method improved for making particle size analyses of soils. Agronomy Journal. 1962; 54: 464-465. https://doi.org/10.2134/agronj1962.00021962005400050028x

4. Bremner, J. (1965). Total Nitrogen. Methods of Soil Analysis: Part 2 Chemical and Microbiological Properties, 9, 1149-1178. https://doi/abs/10.2134/agronmonogr9.2.c32

5. Bruce, R. C., \& Rayment, G. (1982). Analytical methods and interpretations used by the Agricultural Chemistry Branch for soil and land use surveys: Queensland Department of Primary Industries.

6. Charman, P., \& Roper, M. (2007). Soil organic matter. In 'Soils-their properties and management'. $3^{\text {rd }}$ edn.(Eds PEV Charman and BW Murphy.) pp. 276-285: Oxford University Press: Melbourne.

7. Chemists, A. o. O. A. (1995). Official methods of analysis of AOAC International.

8. CSA (2017). Agricultural Sample Survey: Report on Area and Production of Major Crops. Addis Ababa, Ethiopia.

9. CSA (2019). Agricultural Sample Survey: Report on Area and Production of Major Crops. Addis Ababa, Ethiopia.

10. Dumas, Y., Dadomo, M., Di Lucca, G., \& Grolier, P. (2000). Review of the influence of major environmental and agronomic factors on the lycopene content of tomato fruit. Paper presented at the II Balkan Symposium on Vegetables and Potatoes 579.

11. Dumas, Y., Dadomo, M., Di Lucca, G., \& Grolier, P. (2003). Effects of environmental factors and agricultural techniques on antioxidantcontent of tomatoes. Journal of the Science of Food and Agriculture, 83(5), 369-382. 
12. Endale, K. (2011). Fertilizer Consumption and Agricultural Productivity in Ethiopia. Ethiopian Development Research Institute (EDRI): Working Paper 003, Addis Ababa, Ethiopia.

13. EthioSIS. (2014). Soil fertility status and fertilizer recommendation atlas for Tigray regional state, Ethiopia: Addis Ababa Ethiopia.

14. Etissa, E., Dechassa, N., Alamirew, T., Alemayehu, Y., \& Desalegn, L. (2013). Growth and yield components of tomato as influenced by nitrogen and phosphorus fertilizer applications in different growing seasons. Ethiopian Journal of Agricultural Sciences, 24(1), 57-77.

15. Gemechis, A. O., Struik, P. C., \& Emana, B. (2012). Tomato production in Ethiopia: constraints and opportunities. Tropentag 2012, International Research on Food Security, Natural Resource Management and Rural Development. Resilience of Agricultural Systems against Crises: Book of Abstracts, 373.

16. Haileslassie, A., Priess, J., Veldkamp, E., Teketay, D., \& Lesschen, J. P. (2005). Assessment of soil nutrient depletion and its spatial variability on smallholders' mixed farming systems in Ethiopia using partial versus full nutrient balances. Agriculture, ecosystems \& environment, 108(1), 1-16. https://doi.org/10.1016/j.agee.2004.12.010

17. Hazelton, P., \& Murphy, B. (2016). Interpreting soil test results: What do all the numbers mean? : CSIRO publishing.

18. Hedge, D. M. (1997). Nutrient requirements of Solanaceous vegetable crops. Food and Fertilizer Techology. Center for the Asian and Pacific Region Extension Bulletin, Taipei, 441, 449.

19. Holford, I., \& Cullis, B. R. (1985). Effects of phosphate buffer capacity on yield response curvature and fertilizer requirements of wheat in relation to soil phosphate tests. Soil Research, 23(3), 417-427.

20. Kelly, T. W., G. Boyhan. (2010). Commercial tomato production handbook. Univ. of Georgia Coop. Ext. Res. Bul.1312.

21. Khan, K. S., \& Joergensen, R. G. (2009). Changes in microbial biomass and P fractions in biogenic household waste compost amended with inorganic P fertilizers. Bioresource technology, 100(1), 303309. https://doi.org/10.1016/j.biortech.2008.06.002

22. Kirimi, J., Itulya, F., \& Mwaja, V. (2011). Effects of nitrogen and spacing on fruit yield of tomato. African Journal of Horticultural Science, 5.

23. Kuscu H. Turhan A., Ozmen N., Aydinol P., and Demir O. (2014). Optimizing Levels of Water and Nitrogen Applied through Drip Irrigation for Yield, Quality, and Water Productivity of Processing Tomato (Lycopersicon esculentum Mill.) Hort. Environ. Biotechnol. 55(2):103-114. 2014. http://doi.10.1007/s13580-014-0180-9

24. Lemma, D., Yayeh, Z., \& Herath, E. (1992, December). Agronomic studies on Tomato and Capsicum. In Horticulture Research and Development in Ethiopia: Proceedings of the Second National Horticultural Workshop of Ethiopia (pp. 153-163).

25. Lu, C., \& Zhang, J. (2000). Photosynthetic CO2 assimilation, chlorophyll fluorescence and photoinhibition as affected by nitrogen deficiency in maize plants. Plant Science, 151(2), 135-143. https://doi.org/10.1016/S0168-9452(99)00207-1 
26. May, D., \& Gonzales, J. (1993). Irrigation and nitrogen management as they affect fruit quality and yield of processing tomatoes. Paper presented at the V International Symposium on the Processing Tomato 376. 10.17660/ActaHortic.1994.376.28

27. Metson, A. J. (1957). Methods of chemical analysis for soil survey samples. Soil Science, 83(3), 245.

28. Mishra, B., Gowda, A., \& Seshadri Reddy, S. (2010). Impact of graded levels of N, P, K on yield, quality and nutrient uptake of three leaf curl resistant tomato varieties. Karnataka Journal of Agricultural Sciences, $17(1)$.

29. Olaniyi, J., Akanbi, W., Adejumo, T., \& Akande, O. (2010). Growth, fruit yield and nutritional quality of tomato varieties. African Journal of Food Science, 4(6), 398-402.

30. Olsen, S. R. (1954). Estimation of available phosphorus in soils by extraction with sodium bicarbonate: US Department of Agriculture.

31. Pandey, I. B., Dwivedi, D. K., \& Pandey, R. K. (2007). Efficacy of herbicides and fertilizer management on weed dynamics in wheat (Triticum aestivum). Indian Journal of Agronomy, 52(1), 49-52

32. Ronga, D., Pentangelo, A., \& Parisi, M. (2020). Optimizing N Fertilization to Improve Yield, Technological and Nutritional Quality of Tomato Grown in High Fertility Soil Conditions. Plants, 9(5), 575.

33. Roy, S. S., Khan, M. S. I., \& Pall, K. K. K. K. (2011). Nitrogen and phosphorus efficiency on the fruit size and yield of capsicum. Journal of Experimental Sciences.

34. Sainju, U. M., Dris, R., \& Singh, B. (2003). Mineral nutrition of tomato. Food, Agriculture \& Environment, 1(2), 176-183.

35. Santamaria, P. 2006. Nitrate in vegetables: Toxicity, content, intake and EC regulation. J. Sci. Food Agric. 86,10-17.

36. Shi, J., \& Maguer, M. L. (2000). Lycopene in tomatoes: chemical and physical properties affected by food processing. Critical reviews in food science and nutrition, 40(1), 1-42. https://doi.org/10.1080/10408690091189275

37. Simonne, A., Fuzere, J., Simonne, E., Hochmuth, R., \& Marshall, M. (2007). Effects of nitrogen rates on chemical composition of yellow grape tomato grown in a subtropical climate. Journal of plant nutrition, 30(6), 927-935. https://doi.org/10.1080/15226510701375465

38. Taiwo, L., Adediran, J., \& Sonubi, O. (2007). Yield and quality of tomato grown with organic and synthetic fertilizers. International Journal of Vegetable Science, 13(2), 5-19.

https://doi.org/10.1300/J512v13n02_02

39. Tekalign, T., Haque, I., \& Aduayi, E. A. (1991). Soil, plant, water, fertilizer, animal manure and compost analysis. Working document, (13).

40. Van Reeuwijk, L. (1993). Procedures for Soil Analysis. International Soil Reference and Information Centre (ISRIC). Wageningen. Netherlands.

41. Walkley, A., \& Black, I. A. (1934). An examination of the Degtjareff method for determining soil organic matter, and a proposed modification of the chromic acid titration method. Soil Science, 37(1), 
29-38.

42. Wang, Y. T., Huang, S. W., Liu, R. L., \& Jin, J. Y. (2007). Effects of nitrogen application on flavor compounds of cherry tomato fruits. Journal of Plant Nutrition and Soil Science, 170(4), 461-468. http://doi/abs/10.1002/jpln.200700011

43. Warner, J., Zhang, T., \& Hao, X. (2004). Effects of nitrogen fertilization on fruit yield and quality of processing tomatoes. Canadian Journal of Plant Science, 84(3), 865-871. https://doi.org/10.4141/P03-099

44. Wiersinga, R. C., \& de Jager, A. (2009). Business opportunities in the Ethiopian fruit and vegetable sector: Ministry of Agriculture, Nature and Food Quality.

45. Willcox, J. K., Catignani, G. L., \& Lazarus, S. (2003). Tomatoes and Cardiovascular Health, Critical Reviews in Food Science and Nutrition, 43:1, 1-18.http://dx.doi.org/10.1080/10408690390826437

46. Zdravković, J., Marković, Z., Zdravković, M., Damjanović, M., \& Pavlović, N. (2004). Relation of mineral nutrition and content of lycopene and $\beta$-carotene in tomato (Lycopersicon esculentum Mill.) fruits. Paper presented at the III Balkan Symposium on Vegetables and Potatoes 729. http://10.17660/ActaHortic.2007.729.27

\section{Figures}


Location Map of Study Site
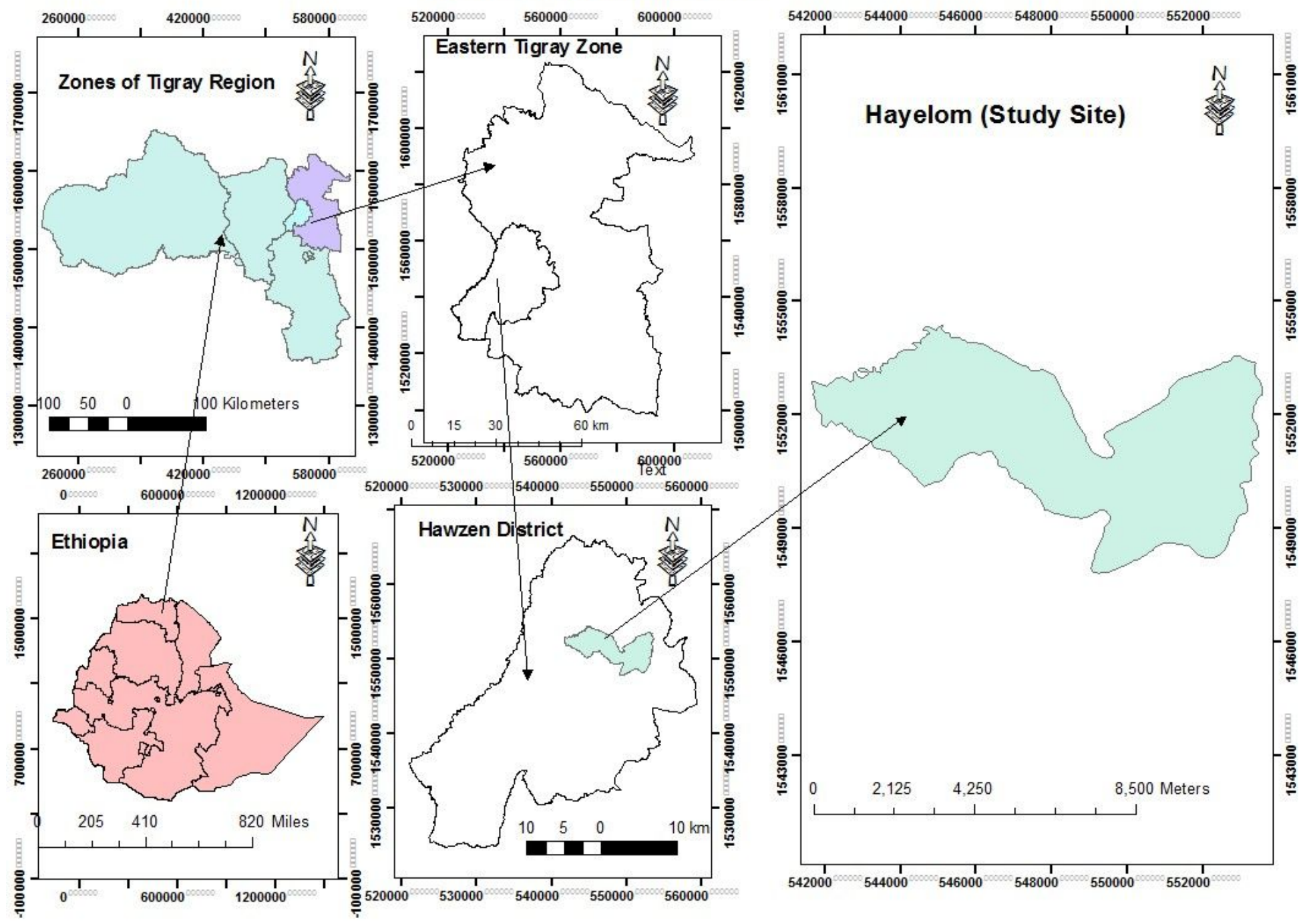

Figure 1

Map of the study area Note: The designations employed and the presentation of the material on this map do not imply the expression of any opinion whatsoever on the part of Research Square concerning the legal status of any country, territory, city or area or of its authorities, or concerning the delimitation of its frontiers or boundaries. This map has been provided by the authors. 


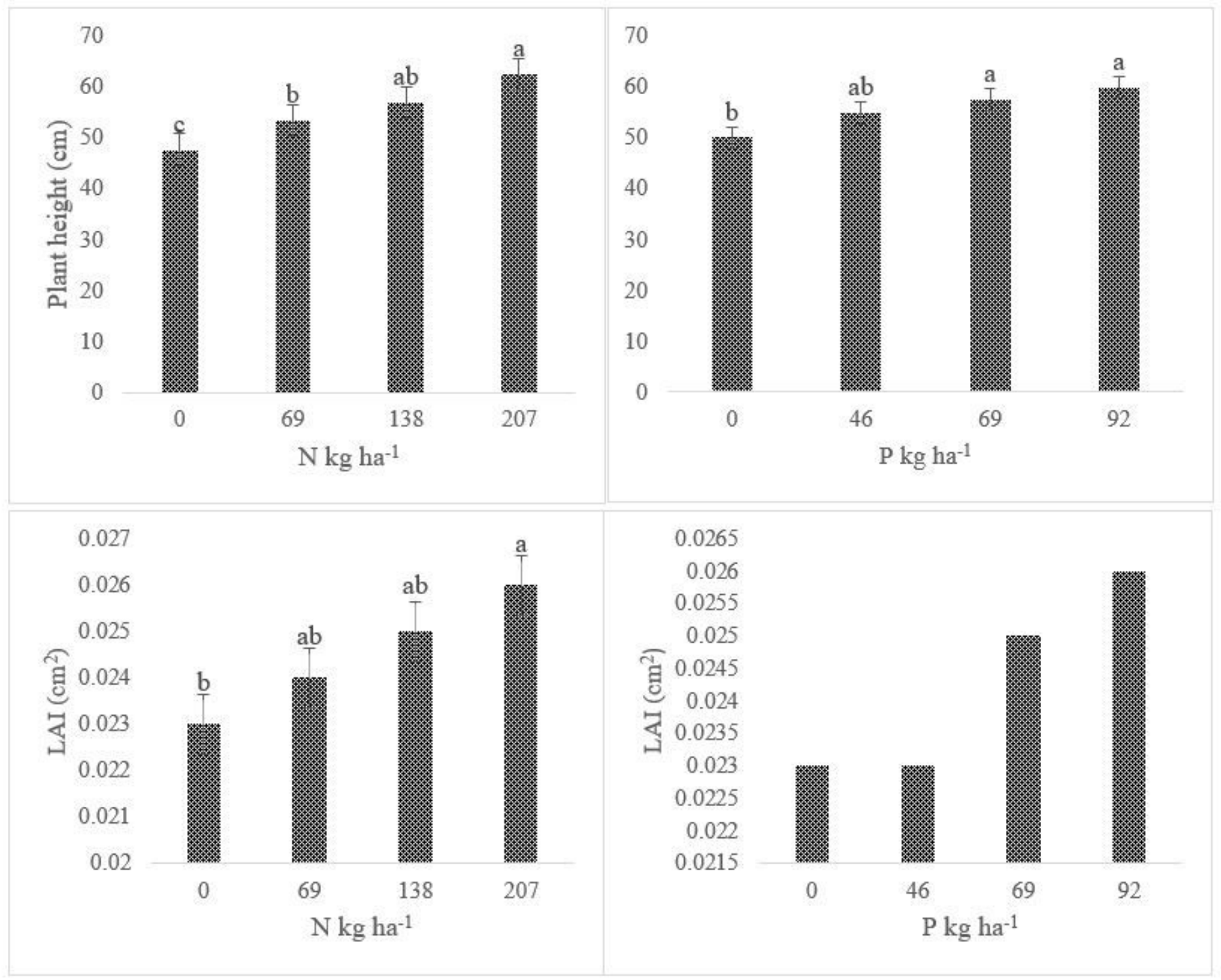

Figure 2

Effects of $\mathrm{N}$ and $\mathrm{P}$ rates on plant height and LAl of tomato 


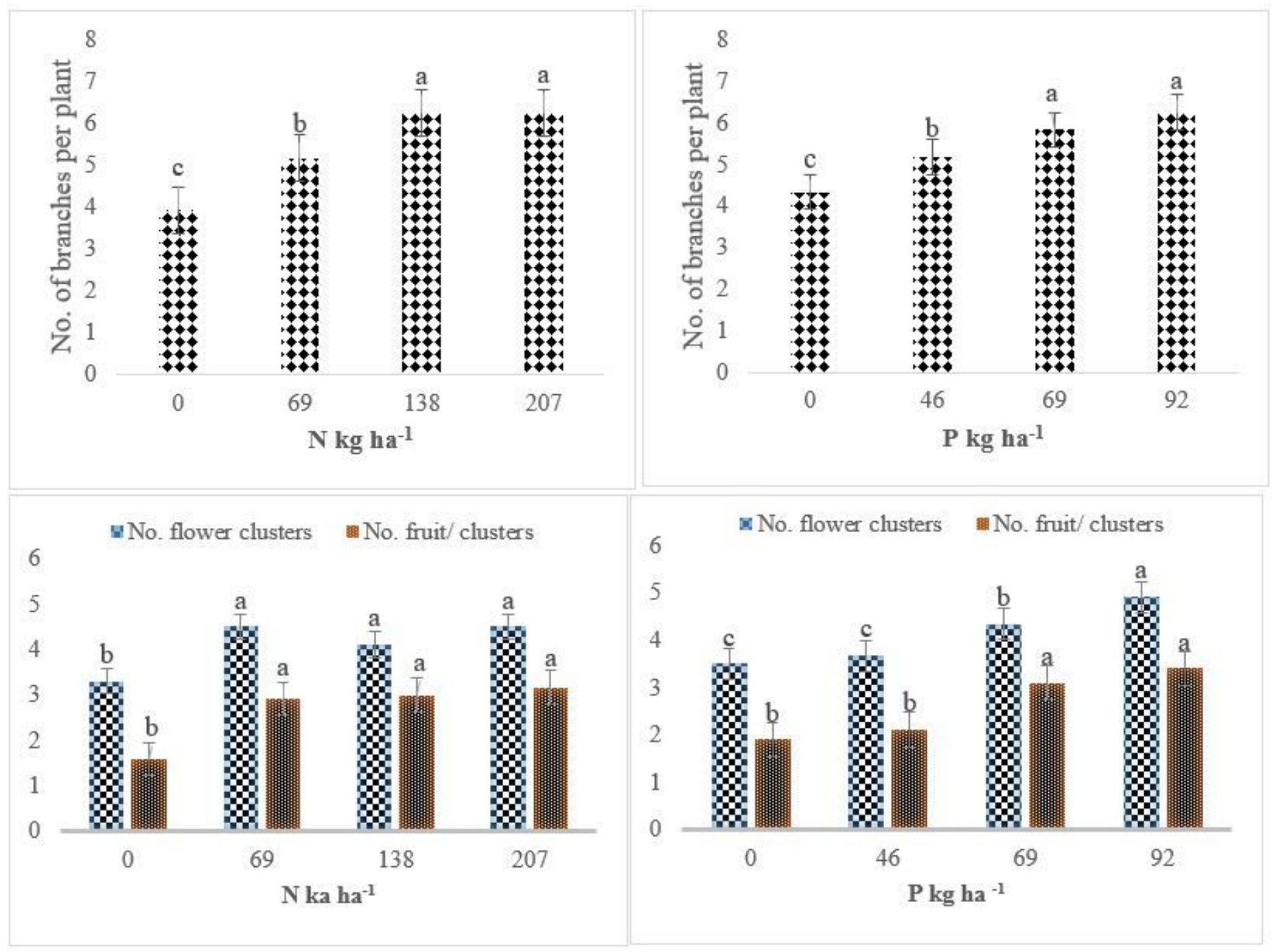

Figure 3

Number of branches per plant, flower cluster and fruit per cluster as affected by different rates of $\mathrm{N}$ and $\mathrm{P}$ 